\title{
HVOF Cermet Coatings to Improve Sliding Wear Resistance in Engineering Systems
}

\author{
Giovanni Straffelini *(D) and Matteo Federici \\ Dept. Industrial Engineering, University of Trento, 38122 Trento, Italy; matteo_federici@brembo.it \\ * Correspondence: giovanni.straffelini@unitn.it
}

Received: 1 July 2020; Accepted: 9 September 2020; Published: 14 September 2020

check for updates

\begin{abstract}
High-Velocity Oxy-Fuel (HVOF) cermet coatings are widely employed in sliding conditions, due to their optimized microstructure, composed of a carbide phase embedded into a ductile metal matrix. In the present short review, the characteristics and mechanical properties of HVOF cermet coatings are considered, and the dry sliding behaviour of the main types of coatings is analysed at room and high temperature. The role of microstructural parameters, including defects, surface roughness and the nature of the counterface is discussed. The review also considers a specific application, namely HVOF coatings for discs in brake applications. This application is gaining in importance, since it reduces the wear of the braking components and thus the emission of airborne particulate matter.
\end{abstract}

Keywords: HVOF coatings; sliding wear; brake systems

\section{Introduction}

High-Velocity Oxy-Fuel (HVOF) cermet coatings are widely employed in tribological applications featuring sliding conditions, such as sliding bearings, valves and forging dies, and as a substitute for hard chrome plating, and emerging industrial needs make these kind of coatings very attractive for new applications, in particular in the automotive industry [1-3]. WC-Co and $\mathrm{Cr}_{3} \mathrm{C}_{2}-\mathrm{NiCr}$ cermet coatings are typically used on different materials, such as steels or ceramic materials [4-8]. The particularly high wear resistance of these coatings is due to their composite microstructure, composed of a carbide phase embedded into a ductile metal matrix. The carbides act as the reinforcing component while the metal binder increases the coating toughness and binds the carbide particles together [2].

The HVOF process involves a supersonic jet flame produced by the combustion of a mixture of oxygen and fuel. This technique has been developed to decrease the decarburisation and oxidation that occur during conventional thermal spraying processes. Moreover, the reduced presence of oxides and pores inside the microstructure improves the properties of the sprayed coatings [3,4]. The preparation of the substrate is fundamental to improve its adhesion with the coating. Typically, the surfaces of the components to be coated are first degreased and then sandblasted to increase their surface roughness and promote the mechanical interlocking between the substrate and the coating. In some cases, to improve the adhesion, intermediate bond layers made of Mo or other alloys are deposited.

Depending on the HVOF gun used and the coating to be deposited, several types of fuels can be employed. The most common are hydrogen, propane, kerosene (aviation grade) and liquefied petroleum gas (LPG). Since liquid fuels have several advantages over gaseous fuels, the latest technology is mainly based on the use of liquid fuels. The sprayed particles reach speeds in excess of $500 \mathrm{~m} / \mathrm{s}$ and temperatures of up to $2300 \mathrm{~K}$ [3]. In general, an increase in the oxygen flow rate leads to an increase in both the particle temperature and speed. However, if the oxygen flow rate is too high, a decrease in particle temperature is observed, due to the oxygen excess leading to a combustion with a lower efficiency. Increasing the kerosene flow rate also leads to an increase in both particle 
temperature and speed. Additionally, in this case, at a critical flow rate, the particle temperature starts decreasing, because of the non-stoichiometric combustion and the cooling produced by the excess in kerosene [6]. Other relevant process parameters are the powder feed rate and the spraying distance. At a low powder feed rate (typically below $30 \mathrm{~g} / \mathrm{min}$ ) the particles overheat, inducing a loss in hardness and an increase in the residual porosity of the sprayed coating. At high powder feed rates (typically in excess of $60 \mathrm{~g} / \mathrm{min}$ ), the flight time of the particles inside the flame is too low, leading to an improper melting of the powder which, again, reduces the hardness and increases the residual porosity of the sprayed coating [7,9]. The spraying distance influences both the temperature and the speed of the sprayed particles; an increase in the spraying distance leads to a decrease in the particle temperature and speed, due to the cooling effect and to the drag force exerted on the stream of the semi-molten particles by the surrounding air. However, a reduction in the spraying distance below 150-200 mm produces an increase in the porosity and a loss in the hardness due to the kinetic energy variations of the in-flight particles [7,10]. The optimal spraying distance is found to be in the range 200-350 $\mathrm{mm}[7,9]$. A summary of the most common spraying parameters for HVOF cermet coatings is given in Table 1. It is clear that the process parameters have to be properly optimised to obtain the best hardness and microstructural properties and, in the end, the best sliding performances. After deposition, the coatings are characterised by a quite high roughness (typical $R_{a}$ values between $2-6 \mu \mathrm{m}$ ). For most applications, surface roughness is reduced by polishing to $\mathrm{R}_{\mathrm{a}}=0.1 \mu \mathrm{m}$ or less.

Table 1. Summary of the HVOF process parameters $[1,6,7,9,11,12]$.

\begin{tabular}{cc}
\hline Process Parameter & Value \\
\hline Oxygen flow rate & $(1.8-60) \mathrm{m}^{3} / \mathrm{h}$ \\
Hydrogen flow rate & $(3.6-40) \mathrm{m}^{3} / \mathrm{h}$ \\
Kerosene flow rate & $(20-30) \mathrm{L} / \mathrm{h}$ \\
Carrier gas & Nitrogen \\
Spraying distance & $(200-350) \mathrm{mm}$ \\
Powder feed rate & $(25-65) \mathrm{g} / \mathrm{min}$ \\
\hline
\end{tabular}

The process parameters summarised in Table 1 mainly refer to the deposition of conventional powders, with a particle size of 5-60 $\mu \mathrm{m}$. For the deposition of nano-sized powders, the process parameters should be modified to consider the higher specific surface area, which could cause a more rapid decarburisation and the formation of higher amounts of parasitic phases [2].

In the present short review, the main characteristics and mechanical properties of HVOF cermet coatings are firstly considered. Then, the dry sliding behaviour of the main types of coatings is analysed at room and high temperature, with special emphasis on the role of microstructural parameters, including defects and surface roughness. To our knowledge, no specific reviews on the (dry) sliding wear of these coatings are present in the literature. In addition, the available literature data are obtained using different testing conditions, making very difficult to have a reliable comparison. Finally, the review considers an emerging application, namely HVOF coatings for discs in brake applications for the automotive industry. This application is gaining in importance, since it reduces the wear of the braking components and thus the emission of airborne particulate matter. The example aims to highlight the versatility of this type of coatings, which is able to excel in ever new applications, meeting the most demanding engineering requirements.

\section{Microstructure of WC-Co, WC-CoCr and $\mathrm{Cr}_{3} \mathrm{C}_{2}-\mathrm{NiCr} \mathrm{HVOF}$ Coatings}

The microstructure of cermet coatings is strictly related to the deposition parameters. In particular, the maximum temperature and the time spent by the particles at that temperature strongly affect the final microstructure. This is because, from a thermodynamic viewpoint, in the temperature range between 2000 and $3000 \mathrm{~K}$, the $\mathrm{W}_{2} \mathrm{C}$ phase is more stable than the WC phase. Therefore, increasing particle temperature leads to a decarburisation of the WC phase with the consequent precipitation 
of $\mathrm{W}_{2} \mathrm{C}$, which is harder and more brittle than WC (3000 kg/mm ${ }^{2}$ with respect to $\left.2400 \mathrm{~kg} / \mathrm{mm}^{2}\right)$. Lekatou et al. [2] described the decarburisation mechanism as follows:

- During the spraying process, the periphery of the flying carbide particles reaches high temperature and dissolves into the Co matrix;

- The quenching of the sprayed particles, due to the impact with the cold substrate, produces a rapid decrease in the solubility of $\mathrm{W}$ and $\mathrm{C}$ in $\mathrm{Co}$, leading to the precipitation of a $\mathrm{W}_{2} \mathrm{C}$ layer around a WC core.

Skandan et al. [13] proposed the following decarburisation reactions to describe the evolution of the carbides during spraying: $2 \mathrm{WC} \rightarrow \mathrm{W}_{2} \mathrm{C}+\mathrm{C} ; \mathrm{W}_{2} \mathrm{C} \rightarrow 2 \mathrm{~W}+\mathrm{C} ; 2 \mathrm{C}+\mathrm{O}_{2} \rightarrow 2 \mathrm{CO}$. The decomposition of $\mathrm{W}_{2} \mathrm{C}$ into $\mathrm{W}$ and $\mathrm{C}$ produces an additional shell of $\mathrm{W}$ around the $\mathrm{WC}$ particles. Other parasitic phases, whose formation should be avoided with the correct spray parameters, are the embrittling Co-containing-phases, such as $\mathrm{Co}_{3} \mathrm{~W}_{3} \mathrm{C}, \mathrm{CoW}_{6} \mathrm{C}$ and $\mathrm{Co}_{6} \mathrm{~W}_{4} \mathrm{C}$ (also-called $\eta$-phases) [14].

Regarding Cr-carbides, above $2500 \mathrm{~K}$ the most stable phase is $\mathrm{Cr}_{23} \mathrm{C}_{6}$ followed by $\mathrm{Cr}_{7} \mathrm{C}_{3}$ and $\mathrm{Cr}_{3} \mathrm{C}_{2}$. In $\mathrm{HVOF}$ coatings containing $\mathrm{Cr}_{3} \mathrm{C}_{2}$, typically used for their excellent high-temperature tribological performance, different decarburisation mechanisms have been proposed: $\mathrm{Cr}_{7} \mathrm{C}_{3}$ forms following the decarburisation of $\mathrm{Cr}_{3} \mathrm{C}_{2}$ while $\mathrm{Cr}_{23} \mathrm{C}_{6}$ precipitates during the HVOF process [1]. Zimmermann and Kreye [15] stated that the X-ray diffraction peaks of $\mathrm{Cr}_{7} \mathrm{C}_{3}$ and $\mathrm{Cr}_{23} \mathrm{C}_{6}$ overlap with those of $\mathrm{NiCr}$ and $\mathrm{Cr}_{3} \mathrm{C}_{2}$, making their detection very difficult.

In general, HVOF cermet coatings display a splat-like microstructure due to the impacts of partially melted droplets followed by their rapid solidification. Some residual porosity is found in the interlamellar regions (the typical residual porosities of HVOF coatings are below 2-3\%). This splat-like microstructure leads to the anisotropic mechanical properties of sprayed coatings. A further source of anisotropy is related to the WC particles that remain in a solid state during spraying. They may retain their original angular morphology in the microstructure or have a rounded appearance. The rounded morphology is a result of a WC dissolution into the matrix with the formation of an external irregular-shaped $\mathrm{W}_{2} \mathrm{C}$ phase and, possibly, a nanocrystalline/amorphous matrix phase [11].

\section{Mechanical Properties of HVOF Hard Coatings}

The mechanical properties of HVOF cermet coatings depend on various parameters, including process parameters (Table 1), feedstock powder chemistry and particle size, initial phase content and carbide grain size, which influence the final microstructure of the coatings [1].

The process parameters, in particular, determine the particle temperature during spraying, which has been shown to be strongly related to the coating hardness [6]. In general, coating hardness increases with particle temperature. It is suggested that high process temperatures cause decarburisation and the dissolution of $\mathrm{W}, \mathrm{Cr}$ and $\mathrm{C}$ into the metal matrix ( $\mathrm{CoCr}$ or $\mathrm{NiCr}$ ). As a consequence, the coating hardness is increased since the reduction in the volume fraction of WC carbides is more than compensated by the hardness increase of the matrix and, possibly, by a higher content of the harder $\mathrm{W}_{2} \mathrm{C}$ carbides.

Usmani et al. [16] investigated the properties of WC-17Co coatings obtained with starting powders containing three different carbide size distributions, with median size of $1.2 \mu \mathrm{m}$ (fine), $3.8 \mu \mathrm{m}$ (medium) and $7.9 \mu \mathrm{m}$ (coarse). The coatings contained a significant amount of $\mathrm{W}_{2} \mathrm{C}$ and $\mathrm{W}$. Selected microstructural and mechanical properties are listed in Table 2. The microhardness values were found to be slightly increased by decreasing the carbide size, because of the increased mean free path and the decreased $\mathrm{W}_{2} \mathrm{C}$ content of the coarser particles. The coating fracture toughness follows the opposite trend, and this was attributed by the authors to the higher $\mathrm{W}_{2} \mathrm{C}$ content of the finer carbide particles. In addition, the fracture toughness is lower perpendicularly to the spraying direction, because of the rather low interfacial bonding between the coating splat interfaces. 
Table 2. Microstructural and mechanical properties of the HVOF WC-Co coatings investigated by Usmani et al. [16].

\begin{tabular}{cccc}
\hline & Fine & Medium & Coarse \\
\hline Median carbide size, $\mu \mathrm{m}$ & 1.2 & 3.8 & 7.9 \\
\hline Mean free path, $\mu \mathrm{m}$ & 0.42 & 1.01 & 1.47 \\
\hline $\mathrm{W}_{2}$ C, wt. $\%$ & 68 & 48 & 48 \\
\hline $\begin{array}{c}\text { Microhardness, } \mathrm{kg} / \mathrm{mm}^{2} \\
\text { (obtained from Knoop tests) }\end{array}$ & 1274 & 1244 & 1233 \\
\hline Mean fracture toughness, MPa $\mathrm{m}^{1 / 2}$ & 4.4 & 5.7 & 6.1 \\
\hline
\end{tabular}

La Vecchia et al. [17] investigated the properties of three different HVOF coatings: WC-12Co, WC-10Co4Cr and $\mathrm{Cr}_{3} \mathrm{C}_{2}-25 \mathrm{NiCr}$. The obtained microhardness values were 1260,1255 and $1060 \mathrm{~kg} / \mathrm{mm}^{2}$, respectively. The fact that the $\mathrm{Cr}_{3} \mathrm{C}_{2}$-based coating had the lowest hardness was attributed to the higher metallic binder content and, most of all, to the lower hardness of $\mathrm{Cr}$ carbide $\left(1400 \mathrm{~kg} / \mathrm{mm}^{2}\right)$.

The prediction and interpretation of the hardness and fracture toughness of HVOF cermet coatings are not always straightforward, because of the large number of microstructural parameters that may play a role. Nahvi et al. [11] investigated different WC-based coatings, measuring their microhardness, porosity and fracture toughness. The investigated cermets were WC-Co (abbreviated to WC-C), WC-FeCrAl (WC-F) and WC-NiMoCrFeCo (WC-N). Table 3 lists the microstructural and mechanical properties. The total volume fraction of carbides in WC-F and WC-N was almost the same, but WC-N displayed a much lower microhardness. The authors attributed this result to the higher $\mathrm{W}_{2} \mathrm{C}$ content $\left(\mathrm{W}_{2} \mathrm{C} / \mathrm{WC}\right.$ ratio equal to 40.42$)$. Even though $\mathrm{W}_{2} \mathrm{C}$ has a higher hardness than $\mathrm{WC}$, the $\mathrm{W}_{2} \mathrm{C}$ phase surrounding the WC grains decreases the cohesion of the grains with the matrix, deteriorating both the hardness and the fracture toughness. The WC-C coating, which had the lowest fraction of carbides, showed the highest fracture toughness value and an intermediate value of hardness.

Table 3. Microstructural and mechanical properties of the HVOF coatings investigated by Nahvi et al. [11].

\begin{tabular}{cccccc}
\hline Designation & $\begin{array}{c}\text { Carbide Phase } \\
{[\mathbf{v o l .} \% \text { ] }}\end{array}$ & $\begin{array}{c}\left.\mathbf{W}_{\mathbf{2}} \mathbf{C} / \mathbf{W C}\right) \\
\text { Ratio }\end{array}$ & $\begin{array}{c}\text { Porosity } \\
{[\mathbf{v o l .} \%]}\end{array}$ & $\begin{array}{c}\text { Microhardness } \\
{[\mathbf{H V 0 . 3}]}\end{array}$ & $\begin{array}{c}\text { Mean } \mathbf{K}_{\mathbf{I C}} \\
{[\mathbf{M P a} \sqrt{\mathbf{m}}]}\end{array}$ \\
\hline WC-C & 55 & 9.14 & 1.8 & $1305 \pm 71$ & $5.9 \pm 0.13$ \\
\hline WC-F & 58 & 12.48 & 5.1 & $1498 \pm 82$ & $3.1 \pm 0.23$ \\
\hline WC-N & 59 & 40.42 & 2.2 & $1254 \pm 38$ & $2.8 \pm 0.27$ \\
\hline
\end{tabular}

\section{Room Temperature Sliding Wear Behaviour of HVOF Coatings}

In the paper cited above, La Vecchia et al. [17] investigated the dry sliding behaviour of three different HVOF coatings: WC-12Co; WC-10Co4Cr; $\mathrm{Cr}_{3} \mathrm{C}_{2}-25 \mathrm{NiCr}$. All samples were ground to a surface roughness of $R_{a}=0.1 \mu \mathrm{m}$ and the tests were performed using a block-on-ring test. Both blocks and rings were coated. The results are shown in Table 4, where the experimental specific wear rates (given by the ratio of the wear volume to the applied load and sliding distance, and indicated hereafter by $K_{a}$ ) are reported as a function of sliding speed. The WC-12Co coating shows mild wear (with a specific wear coefficient, $K_{a}$, lower than $10^{-15} \mathrm{~m}^{2} / \mathrm{N}$ ), which is quite similar to that typically displayed by as-sintered WC-Co hard metals [8]. The second coating, however, displays a much larger $\mathrm{K}_{\mathrm{a}}$ (at $0.2 \mathrm{~m} / \mathrm{s}$ ) even though its hardness is similar to that of the first coating. The different behaviour was attributed to the presence of the $\eta$-phase (pre-existing in the starting powder), which strongly embrittled the coating, promoting the formation and removal of wear fragments. The third coating shows a $K_{\mathrm{a}}$ similar to that of the second. This last coating does not contain the $\eta$-phase, but its hardness is lower than that of the first coating. 
Table 4. Specific wear rate in $\mathrm{m}^{2} / \mathrm{N}$ vs. sliding speed for three HVOF coatings dry sliding against a counterface of the same type in a block-on-ring configuration ([17]).

\begin{tabular}{|c|c|c|}
\hline Material & $0.2 \mathrm{~m} / \mathrm{s}$ & $0.6 \mathrm{~m} / \mathrm{s}$ \\
\hline WC-12Co & $4.810^{-16}$ & $110^{-16}$ \\
\hline WC-10Co4Cr & $210^{-14}$ & $510^{-15}$ \\
\hline $\mathrm{Cr}_{3} \mathrm{C}_{2}-25 \mathrm{NiCr}$ & $1.910^{-14}$ & $1.310^{-14}$ \\
\hline
\end{tabular}

Sudaprasert et al. [18], investigated the sliding wear behaviour of two WC-12Co coatings obtained using kerosene (liquid fuel) or hydrogen (gas fuel), with a hardness of 1230 and $1280 \mathrm{~kg} / \mathrm{mm}^{2}$, respectively. The tests were conducted in a ball-on-disc configuration, using a ceramic $\left(\mathrm{Al}_{2} \mathrm{O}_{3}\right)$ ball as a counterface. The obtained $\mathrm{K}_{\mathrm{a}}$-values were approximately $10^{-15} \mathrm{~m}^{2} / \mathrm{N}$ and $210^{-16}$ $\mathrm{m}^{2} / \mathrm{N}$, in agreement with the results of La Vecchia et al. [17].

The specific wear coefficient, $K_{a}$, is expected to be directly proportional to the coating hardness. As seen, however, microstructural defects, such as the presence of embrittling phases, residual pores and insufficient bonding between the lamellae, may exert a very important role and render the hardness-wear relationship unreliable. A further complication to this is given by the roughness of the coatings and the counterparts. As an example, Picas et al. [19] investigated the sliding behaviour of different $\mathrm{Cr}_{3} \mathrm{C}_{2}$-CoNiCrAlY coatings with a hardness of between approximately 1130 and $1290 \mathrm{~kg} / \mathrm{mm}^{2}$. Pin-on-disc tests were carried out using WC-6Co spherical pins sliding against coated discs. The disc wear coefficients were found to vary between $1.710^{-14} \mathrm{~m}^{2} / \mathrm{N}$ and $810^{-15} \mathrm{~m}^{2} / \mathrm{N}$. The $\mathrm{K}_{\mathrm{a}}$-values were found to decrease as the coating hardness increased. Furthermore, they were higher than the values previously reported for coatings with similar hardness values. Recently, Bolelli et al. [20] studied the sliding wear of WC-CoCr and WC- $(\mathrm{W}, \mathrm{Cr})_{2} \mathrm{C}-\mathrm{Ni}$ coatings with a roughness of $0.02 \mu \mathrm{m}$. A ball-on-disc apparatus was used, with a ball made of alumina. Some of the microstructural and mechanical properties, including the specific wear coefficients, are listed in Table 5. In this case, the $\mathrm{K}_{\mathrm{a}}$-values are proportional to the coating microhardness, but they are from one to two orders of magnitude lower than the values previously reported.

Table 5. Microstructural and mechanical properties of the HVOF coatings investigated by Bolelli et al. [20].

\begin{tabular}{ccccc}
\hline Material & Microhardness $\left[\mathbf{k g} / \mathbf{m m}^{2}\right]$ & $\begin{array}{c}\text { Mean } \mathbf{K}_{\mathbf{I C}} \\
{[\mathbf{M P a} \sqrt{\mathbf{m}}]}\end{array}$ & $\begin{array}{c}\text { Friction } \\
\text { Coefficient }\end{array}$ & $\begin{array}{c}\mathbf{K}_{\mathbf{a}} \text {, } \\
{\left[\mathbf{m}^{2} / \mathbf{N}\right]}\end{array}$ \\
\hline WC-CoCr & 1131 & 5.06 & 0.44 & app. $610^{-17}$ \\
\hline WC-(W, Cr) ${ }_{2} \mathrm{C}-\mathrm{Ni}$ & 1090 & 3.66 & 0.63 & app. $10^{-16}$ \\
\hline
\end{tabular}

The sliding tests discussed so far were carried out using ceramic counterfaces. However, in different applications, metal alloys, and in particular steel, are used as counterparts. Ishikawa et al. [3] studied the sliding wear behaviour of WC- $20 \% \mathrm{Cr}_{3} \mathrm{C}_{2}-7 \% \mathrm{Ni}$ by means of a pin-on-disc apparatus. The discs were coated, and their surface roughness was decreased by polishing to $0.01-0.02 \mu \mathrm{m}$. Iron pins (with a hardness of $138 \mathrm{HV}$ ) were used as counterparts. Different mixtures of oxygen and fuel were used for the spray process. The sprayed coatings had quite high microhardness values, approximately between 1200 and $1650 \mathrm{~kg} / \mathrm{mm}^{2}$. The obtained $\mathrm{K}_{\mathrm{a}}$-values are typical of the mild wear regime for both pins and discs. In particular, the wear rate of the coated disc with the highest hardness was not reported because its particularly low weight loss did not allow any detectable weight change before and after wear testing. The recorded friction coefficients were quite high, in the range 0.85-0.91. Quite interestingly, the $\mathrm{K}_{\mathrm{a}}$-values of the iron pins were also low, except one case. The authors consider this result to be due to the attainment, during sliding, of a tribo-oxidative wear, with the formation of protective oxide scales. Similar results were obtained by Sidhu et al. [4]. The authors investigated the wear performance of WC-Co and $\mathrm{Cr}_{3} \mathrm{C}_{2}-\mathrm{NiCr}$ HVOF coated pins sliding against a hardened 
steel (hardness of 62-65 HRC) disc. The roughness of the coatings was reduced to $1.00 \pm 0.32 \mu \mathrm{m}$. The recorded friction coefficient was approximately 0.5 for the WC-Co coating, and 0.78 for the other. The recorded specific wear coefficients were quite low, below $10^{-15} \mathrm{~m}^{2} / \mathrm{N}$, and they were found to increase during sliding, although no steady state was reached before the end of the tests.

\section{High Temperature Wear Behaviour of HVOF Coatings}

HVOF cermet coatings are particularly suitable for high-temperature applications, since they are able to retain their hardness up to $600{ }^{\circ} \mathrm{C}$ or more. In these applications, ceramic materials are always used as counterparts. Valentinelli et al. [21] carried out pin-on-disc sliding tests at different temperatures, using HVOF WC-17Co coated discs (hardness of $1150 \mathrm{~kg} / \mathrm{mm}^{2}$ ) and alumina balls (hardness equal to $1600 \mathrm{~kg} / \mathrm{mm}^{2}$ ). At room temperature, the $\mathrm{K}_{\mathrm{a}}$-value is quite high (approximately $410^{-14} \mathrm{~m}^{2} / \mathrm{N}$ ), most probably because of abrasive interactions during the sliding. The specific wear rate reaches a minimum at a temperature of about $400{ }^{\circ} \mathrm{C}\left(\mathrm{K}_{\mathrm{a}}\right.$ approximately $\left.710^{-15} \mathrm{~m}^{2} / \mathrm{N}\right)$. In fact, wear was by tribo-oxidation, and as the temperature was increased, the oxide layer was able to better protect the coating from wear. However, if the testing temperature exceeded $400{ }^{\circ} \mathrm{C}$, the oxidation rate became too high and, at the same time, the hardness of the coating decreased. As a result, the specific wear rate increased.

Zhang et al. [22] investigated the high temperature sliding wear behaviour of WC-10Co-4Cr and $\mathrm{Cr}_{3} \mathrm{C}_{2}-25 \%-\mathrm{NiCr}$ coatings by means of a ball-on-disc apparatus. The tests were performed $500^{\circ} \mathrm{C}$ and $600{ }^{\circ} \mathrm{C}$ in a nitrogen atmosphere. The ball material was $\mathrm{Si}_{3} \mathrm{~N}_{4}$. Before the tests, the coated discs were polished to reach a surface roughness lower than $0.35 \mu \mathrm{m}$. The recorded average steady-state friction coefficients are listed in Table 6. As far as the wear behaviour is concerned, for the WC-10Co4Cr coating the measured wear coefficients were $9.610^{-17} \mathrm{~m}^{2} / \mathrm{N}$ at $500{ }^{\circ} \mathrm{C}$ and $4.210^{-17} \mathrm{~m}^{2} / \mathrm{N}$ at $600{ }^{\circ} \mathrm{C}$. For the $\mathrm{Cr}_{3} \mathrm{C}_{2}-25 \mathrm{NiCr}$ coatings, the authors were not able to measure the wear track, demonstrating the well-known excellent high temperature wear resistance of this kind of coating. The $\mathrm{K}_{\mathrm{a}}$-values are extremely low, but it is not clear if the absence of oxygen in the testing atmosphere played a particular role in this.

Table 6. Friction coefficient of the coatings at the testing temperature [22].

\begin{tabular}{ccc}
\hline Coating & $\mathbf{5 0 0}{ }^{\circ} \mathrm{C}$ & $\mathbf{6 0 0}{ }^{\circ} \mathrm{C}$ \\
\hline $\mathrm{WC}-10 \mathrm{Co}-4 \mathrm{Cr}$ & 0.59 & 0.44 \\
\hline $\mathrm{Cr}_{3} \mathrm{C}_{2}-25 \mathrm{NiCr}$ & 0.87 & 0.70 \\
\hline
\end{tabular}

In the above-cited investigation, Bolelli et al. [20] studied the sliding wear behaviour (in air) of WC-CoCr and WC-(W,Cr $)_{2} \mathrm{C}-\mathrm{Ni}$ coatings at different temperatures: room temperature, $400{ }^{\circ} \mathrm{C}$, $600{ }^{\circ} \mathrm{C}$ and $750{ }^{\circ} \mathrm{C}$. For temperatures up to $600{ }^{\circ} \mathrm{C}$, the recorded specific wear coefficients were below $110^{-16} \mathrm{~m}^{2} / \mathrm{N}$ for the WC-CoCr coating, and below $410^{-15} \mathrm{~m}^{2} / \mathrm{N}$ for the WC-(W,Cr $)_{2} \mathrm{C}-\mathrm{Ni}$ coating, in substantial agreement with the data reported by Zhang et al. [22]. At $750{ }^{\circ} \mathrm{C}$, the specific wear coefficient of the WC- $(\mathrm{W}, \mathrm{Cr})_{2} \mathrm{C}-\mathrm{Ni}$ coating increased to $10^{-14} \mathrm{~m}^{2} / \mathrm{N}$, and became very severe for the WC-CoCr coating (in excess of $10^{-13} \mathrm{~m}^{2} / \mathrm{N}$ ). This confirms that at room and low ambient temperatures, the WC-CoCr coating performs better than cermet coatings based on $\mathrm{Cr}$ carbides. However, at high temperatures, the opposite trend is observed. At room temperature, the observed wear mechanism was the abrasion exerted by the alumina ball asperities, whereas at $400{ }^{\circ} \mathrm{C}$ and $600{ }^{\circ} \mathrm{C}$, the thermal softening of the metal matrix causes a transfer of oxidised material onto the alumina ball, leading to a mild wear regime. At $750^{\circ} \mathrm{C}$, the WC-CoCr underwent severe oxidation of the matrix, which greatly reduced the wear resistance. On the other hand, at $750{ }^{\circ} \mathrm{C}$ the $\mathrm{WC}-(\mathrm{W}, \mathrm{Cr})_{2} \mathrm{C}-\mathrm{Ni}$ was soon covered by a uniform and compact layer of $\mathrm{NiWO}_{4}+\mathrm{CrWO}_{4}$, which protected the surface from severe wear [20]. 


\section{Recently Proposed HVOF Coatings}

Yuan et al. [23] investigated the possibility of improving the hardness and the sliding wear behaviour of WC-Co coatings with the addition of submicron-sized WC particles. A commercial WC-12Co powder with a particle size of $45 \pm 15 \mu \mathrm{m}$ was blended with the submicron-sized WC powder (particle size about $300 \mathrm{~nm}$ ) by ball milling. The microhardness of the coatings was found to increase from approximately $1150 \mathrm{HV}$ for the traditional WC-12Co coating, to approximately $1400 \mathrm{HV}$ for the coating with $5 \%$ of submicron particles. Sliding tests were carried out at room temperature and using $\mathrm{Si}_{2} \mathrm{~N}_{4}$ balls as a counterpart. The experimental $\mathrm{K}_{\mathrm{a}}$-values were found to decrease from $610^{-16} \mathrm{~m}^{2} / \mathrm{N}$ to $5.210^{-16} \mathrm{~m}^{2} / \mathrm{N}$. This decrease was attributed to the submicron-sized particles embedded in the splat interfaces, which hinder the propagation of the wear cracks.

In recent years, the high fluctuation in the price of $\mathrm{Ni}$ and $\mathrm{Co}$ and the possible health issues caused by airborne wear fragments containing $\mathrm{WC}, \mathrm{Co}, \mathrm{Cr}$, and $\mathrm{Ni}$ have become the driving force for replacing the traditional cermet coatings with less expensive Fe-based alloys. Milanti et al. [24] investigated the properties and the tribological behaviour of HVOF-sprayed Fe-Ni-Cr-B-C and Fe-Ni-Cr-Mo-B-C coatings. Ni was added to promote the formation of an austenitic matrix, with a better corrosion resistance than the ferritic matrix; $\mathrm{Cr}$ was added to promote the formation of fine and dispersed carbides; $\mathrm{B}$ was mainly added to favour the formation of a nanocrystalline/amorphous microstructure; Mo was added to promote the formation during sliding of beneficial $\mathrm{MoO}_{3}$ and $\mathrm{NiMoO}_{4}$ which are expected to act as solid lubricants, improving the sliding wear behaviour of the coating [25-27]. These innovative Fe-based coatings were deposited by HVOF on a low carbon steel substrate. The hardness of the coatings was approximately between 600 and 800 HV0.3, and, therefore, slightly lower than the typical hardness values of HVOF cermet coatings. The sliding behaviour of these Fe-based coatings was tested with a ball-on-disc apparatus, using an alumina ball. The wear rates of discs and counterparts are reported in Table 7 (the results relating to a conventional WC-CoCr coating with a microhardness of approximately $1300 \mathrm{HV}$ are also included as a comparison).

Table 7. Wear rates after ball-on-disc tests [24].

\begin{tabular}{ccc}
\hline Coating & $\begin{array}{c}\text { Disc Wear Rate } \\
{\left[\mathbf{m}^{\mathbf{2}} / \mathbf{N}\right]}\end{array}$ & $\begin{array}{c}\text { Alumina Ball Wear Rate } \\
{\left[\mathbf{m}^{2} / \mathbf{N}\right]}\end{array}$ \\
\hline Fe-Ni-Cr-B-C & $3.4510^{-15}$ & $0.10110^{-15}$ \\
\hline Fe-Ni-Cr-Mo-B-C & $3.2510^{-15}$ & $0.09510^{-15}$ \\
\hline WC-CoCr & $0.0610^{-15}$ & $1.15110^{-15}$ \\
\hline
\end{tabular}

The data in Table 7 clearly show that the novel Fe-based coatings have less wear resistance than the conventional WC-CoCr coating, and this is clearly due to their lower hardness. The $\mathrm{K}_{\mathrm{a}}$-values are approximately two orders of magnitude higher. However, it is also seen that the novel Fe-base coatings induce a lower wear on the alumina ball counterfaces (approximately one order of magnitude lower).

Terajima et al. [28] attempted to improve the wear resistance of amorphous Fe-based coatings (FeCrMoCB) by adding WC-12Co particles to the feedstock. Three compositions were investigated, containing $2 \mathrm{wt} . \%, 4 \mathrm{wt} . \%$ and $8 \mathrm{wt} . \%$ of WC-Co reinforcing particles. As a comparison, a coating without WC-Co particles was tested. It was noted that the Fe-based coating contained greater porosity than the coating reinforced with WC-Co particles. In fact, the added carbides were found to fill the cavities at the splat interfaces. As a consequence, the increasing content of WC-Co fraction improved the microhardness of the coatings from approximately $700 \mathrm{HV}$ to approximately $900 \mathrm{HV}$. The sliding behaviour of the coatings was investigated by means of a reciprocating tribometer equipped with an alumina ball. Increasing the content of WC-Co particles resulted in a decrease in friction coefficient from 0.8 to approximately 0.6 , and a reduction in $\mathrm{K}_{\mathrm{a}}$ from $810^{-14}$ to $1.510^{-14} \mathrm{~m}^{2} / \mathrm{N}$. However, these $\mathrm{K}_{\mathrm{a}}$-values are still quite high, due to the relative low hardness of the coatings and the abrasive interaction exerted by WC debris peeled from the coatings. 
More recently, Bolelli et al. [29] also investigated the possibility of reinforcing Fe-based coatings with WC particles. The results show that the $\mathrm{K}_{\mathrm{a}}$-values of the newly developed Fe-based coatings were comparable to those of the traditional WC-CoCr coatings, and lower than $10^{-17} \mathrm{~m}^{2} / \mathrm{N}$, i.e., extremely low. Moreover, the same authors tested different types of Fe-based coatings $[30,31]$ detecting specific wear coefficients in the order of $10^{-15} \mathrm{~m}^{2} / \mathrm{N}$.

To summarise, the specific wear coefficients taken from references $[3,4,6,13,14,18-20,28-31]$ are compared in Figure 1 with an indication of the counterface used during the tribological dry sliding tests. It is seen that $K_{a}$ is quite low (below $10^{-15} \mathrm{~m}^{2} / \mathrm{N}$ ) when hardness is typically in excess of $1200 \mathrm{HV}$. However, the counterface, the coating quality and surface roughness play a paramount role, and this must be considered in designing.

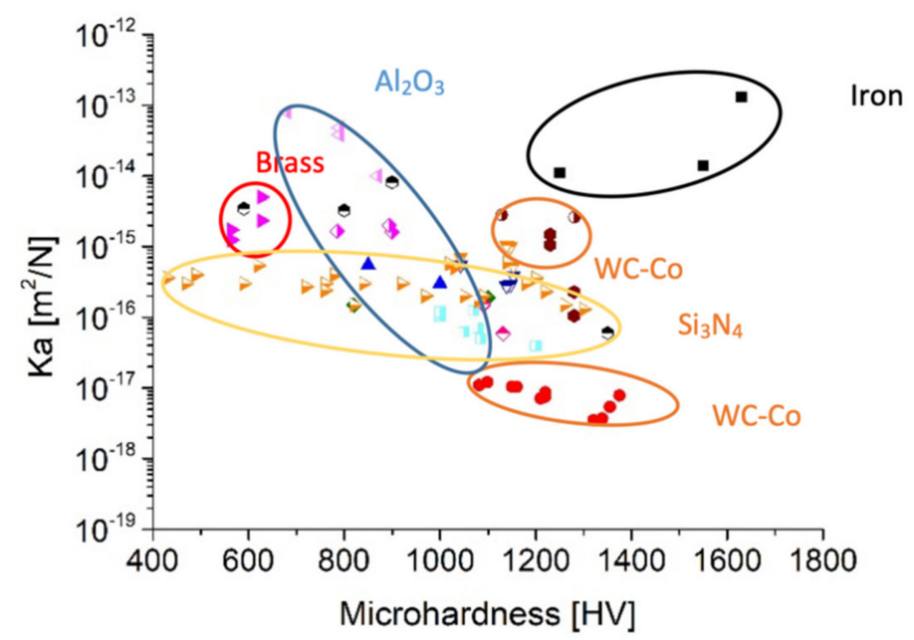

Figure 1. Specific wear coefficients taken from the literature with the indication of the counterfaces used during the tribological tests.

\section{HVOF Cermet Coatings for Brake Discs}

HVOF cermet coatings are quite promising in brake systems that are made of a friction material pad sliding against a rotating disc [32-34]. In fact, disc wear contributes significantly to system wear and also to the emission of wear particles into the environment [35]. Since the release into the environment of wear particles is strictly related to the wear of the components in sliding contact, by increasing the wear resistance of the discs a reduction in the emissions is expected.

Federici et al. [36] studied the influence of the initial surface roughness and skewness of HVOF WC-10Co4Cr coated discs sliding against a commercial low-metallic friction material. The best compromise between the frictional and wear performances and the industrial feasibility of the polishing process was attained at an average surface roughness of approximately $1 \mu \mathrm{m}$. As surface roughness is decreased, the pin wear decreases only slightly whereas the friction coefficient increases considerably. The tribological characterisation was also extended to their running-in behaviour [37] showing the importance of the polishing process.

Federici et al. [32] also investigated the dry sliding behaviour of WC-CoCr and $\mathrm{Cr}_{3} \mathrm{C}_{2}-\mathrm{NiCr}$ coated discs against a commercial friction material, at both room temperature and $300{ }^{\circ} \mathrm{C}$. The steady-state friction coefficients at room temperature were quite high, approximately 0.7 and 0.6 for the WC-CoCr and $\mathrm{Cr}_{3} \mathrm{C}_{2}-\mathrm{NiCr}$ coated discs, respectively, but they were attained after quite a long running-in stage, necessary to form a proper friction layer. When sliding against an uncoated cast iron disc, the running-in is much shorter. In fact, the wear of the disc produces fragments that are oxidised and compacted on the friction material, producing a proper friction layer. This has to be properly taken into account in evaluating the brake performance of the tribological system. At $300^{\circ} \mathrm{C}$, no running-in was observed and the friction coefficient was only slightly reduced. The specific wear coefficients of the coated discs were negligible in all cases. 
Wahlström et al. [38] investigated the emission of airborne particles due to the wear of the materials in brake systems with HVOF cermet coated discs. The results were quite promising, showing that this kind of coating can effectively contribute to the reduction of particulate matter emissions. Menapace et al. [39] extended the study, investigating the chemical and phase composition of the airborne fraction of wear debris collected during dyno-bench tests with WC-CoCr coated discs. One of the main results of the investigation was the detection of some critical components transferred from the coating to the airborne fraction of wear debris, including WC and Co. Since some species of this element are considered as hazardous for the human body [40], they should be removed from coatings used for braking applications. In this respect, the novel Fe-based coatings could be promising, and merit further investigation in the future.

\section{Conclusions and Future Research Directions}

- The dry sliding wear resistance of HVOF cermet coatings is quite high, in particular if their microhardness is in excess of $1200 \mathrm{HV}$ (and no embrittling phases are present).

- Wear rate may increase when using metal (such as steel) counterfaces.

- High wear resistance is also maintained at high temperature (up to at least $400{ }^{\circ} \mathrm{C}$ ).

- HVOF cermet coatings are very effective in reducing brake system wear and also in reducing airborne particulate emissions.

- Surface roughness has to be optimised to obtain an adequate friction coefficient (proper formation of the friction layer) and low wear.

- However, some W and Co were found in collected airborne particles: Co-free coatings need to be developed and optimised for braking applications

To cope with the requirements of new applications, the development of innovative coatings is then often required. In this regard, the recent developments of novel HVOF cermet coatings, with Fe-based or Ni-based matrix and/or submicron sized carbide or oxide particles, can be seen from this perspective. Further research is still required to improve the microstructural characteristics and the mechanical properties of the novel coatings, so that they can better resist damaging mechanisms faced in real dry sliding conditions.

Funding: This research received no external funding.

Conflicts of Interest: The authors declare no conflict of interest.

\section{References}

1. Akhtari Zavareh, M.; Sarhan, A.A.D.M.; Razak, B.B.; Basirun, W.J. The tribological and electrochemical behavior of HVOF-sprayed Cr3C2-NiCr ceramic coating on carbon steel. Ceram. Int. 2015, 41, 5387-5396. [CrossRef]

2. Lekatou, A.; Sioulas, D.; Karantzalis, A.E.; Grimanelis, D. A comparative study on the microstructure and surface property evaluation of coatings produced from nanostructured and conventional WC-Co powders HVOF-sprayed on Al7075. Surf. Coat. Technol. 2015, 276, 539-556. [CrossRef]

3. Ishikawa, Y.; Kuroda, S.; Kawakita, J.; Sakamoto, Y.; Takaya, M. Sliding wear properties of HVOF sprayed WC-20\%Cr3C2-7\%Ni cermet coatings. Surf. Coat. Technol. 2007, 201, 4718-4727. [CrossRef]

4. Sidhu, H.S.; Sidhu, B.S.; Prakash, S. Wear characteristics of $\mathrm{Cr} 3 \mathrm{C} 2 \mathrm{-NiCr}$ and WC-Co coatings deposited by LPG fueled HVOF. Tribol. Int. 2010, 43, 887-890. [CrossRef]

5. Pan, J.; Hu, S.; Yang, L.; Ding, K.; Ma, B. Numerical analysis of flame and particle behavior in an HVOF thermal spray process. Mater. Des. 2016, 96, 370-376. [CrossRef]

6. Picas, J.A.; Punset, M.; Baile, M.T.; Martín, E.; Forn, A. Effect of oxygen/fuel ratio on the in-flight particle parameters and properties of HVOF WC-CoCr coatings. Surf. Coat. Technol. 2011, 205, S364-S368. [CrossRef]

7. Murugan, K.; Ragupathy, A.; Balasubramanian, V.; Sridhar, K. Optimizing HVOF spray process parameters to attain minimum porosity and maximum hardness in WC-10Co-4Cr coatings. Surf. Coat. Technol. 2014, 247, 90-102. [CrossRef] 
8. Straffelini, G. Friction and Wear Methodologies for Design and Control; Springer International Publishing: Cham, Switzerland, 2015; ISBN 9783319058931.

9. Thermsuk, S.; Surin, P. Optimization Parameters of WC-12Co HVOF Sprayed Coatings on SUS 400 Stainless Steel. Procedia Manuf. 2019, 30, 506-513. [CrossRef]

10. Wang, Q.; Chen, Z.; Li, L.; Yang, G. The parameters optimization and abrasion wear mechanism of liquid fuel HVOF sprayed bimodal WC-12Co coating. Surf. Coat. Technol. 2012, 206, 2233-2241. [CrossRef]

11. Nahvi, S.M.; Jafari, M. Microstructural and mechanical properties of advanced HVOF-sprayed WC-based cermet coatings. Surf. Coat. Technol. 2016, 286, 95-102. [CrossRef]

12. Murthy, J.K.N.; Venkataraman, B. Abrasive wear behaviour of WC-CoCr and $\mathrm{Cr}_{3} \mathrm{C}_{2}-20(\mathrm{NiCr})$ deposited by HVOF and detonation spray processes. Surf. Coat. Technol. 2006, 200, 2642-2652. [CrossRef]

13. Skandan, G.; Yao, R.; Kear, B.H.; Qiao, Y.; Liu, L.; Fischer, T.E. Multimodal powders: A new class of feedstock material for thermal spraying of hard coatings. Scr. Mater. 2001, 44, 1699-1702. [CrossRef]

14. Sahraoui, T.; Fenineche, N.E.; Montavon, G.; Coddet, C. Structure and wear behaviour of HVOF sprayed Cr3C2-NiCr and WC-Co coatings. Mater. Des. 2003, 24, 309-313. [CrossRef]

15. Zimmermann, S.; Kreye, H. Chromium carbide coatings produced with various HVOF spray systems. In Proceedings of the Thermal Spray Practical Solutions for Engineering Problems. In Proceedings of the 9th National Thermal Spray Conference, Cincinnati, OH, USA, 7-11 October 1996; Berndt, C.C., Ed.; ASM International: Materials Park, OH, USA, 1996; pp. 147-152.

16. Usmani, S.; Sampath, S.; Houck, D.L.; Lee, D. Effect of Carbide Grain Size on the Sliding and Abrasive Wear Behavior of Thermally Sprayed WC-Co Coatings. Tribol. Trans. 1997, 40, 470-478. [CrossRef]

17. La Vecchia, G.M.; Mor, F.; Straffelini, G.; Doni, D. Microstructure and sliding wear behaviour of thermal spray carbide coatings. Int. J. Powder Metall. 1999, 35, 37-46.

18. Sudaprasert, T.; Shipway, P.H.; McCartney, D.G. Sliding wear behaviour of HVOF sprayed WC-Co coatings deposited with both gas-fuelled and liquid-fuelled systems. Wear 2003, 255, 943-949. [CrossRef]

19. Picas, J.A.; Punset, M.; Menargues, S.; Martín, E.; Baile, M.T. Microstructural and tribological studies of as-sprayed and heat-treated $\mathrm{HVOF} \mathrm{Cr}_{3} \mathrm{C}_{2}-\mathrm{CoNiCrAlY}$ coatings with a CoNiCrAlY bond coat. Surf. Coat. Technol. 2015, 268, 317-324. [CrossRef]

20. Bolelli, G.; Berger, L.M.; Bonetti, M.; Lusvarghi, L. Comparative study of the dry sliding wear behaviour of HVOF-sprayed WC-(W,Cr)2C-Ni and WC-CoCr hardmetal coatings. Wear 2014, 309, 96-111. [CrossRef]

21. Fedrizzi, L.; Valentinelli, L.; Rossi, S.; Segna, S. Tribocorrosion behaviour of HVOF cermet coatings. Corros. Sci. 2007, 49, 2781-2799. [CrossRef]

22. Zhang, W.C.; Liu, L.B.; Zhang, M.T.; Huang, G.X.; Liang, J.S.; Li, X.; Zhang, L.G. Comparison between WC-10Co-4Cr and Cr3C2-25NiCr coatings sprayed on H13 steel by HVOF. Trans. Nonferrous Met. Soc. China (English Ed.) 2015, 25, 3700-3707. [CrossRef]

23. Yuan, J.; Ma, C.; Yang, S.; Yu, Z.; Li, H. Improving the wear resistance of HVOF sprayed WC-Co coatings by adding submicron-sized WC particles at the splats' interfaces. Surf. Coat. Technol. 2016, 285, 17-23. [CrossRef]

24. Milanti, A.; Koivuluoto, H.; Vuoristo, P.; Bolelli, G.; Bozza, F.; Lusvarghi, L. Microstructural Characteristics and Tribological Behavior of HVOF-Sprayed Novel Fe-Based Alloy Coatings. Coatings 2014, 4, 98-120. [CrossRef]

25. Shin, J.H.; Wang, Q.M.; Kim, K.H. Microstructural evolution and tribological behavior of Mo-Cu-N coatings as a function of $\mathrm{Cu}$ content. Mater. Chem. Phys. 2011, 130, 870-879. [CrossRef]

26. Tian, B.; Yue, W.; Fu, Z.; Gu, Y.; Wang, C.; Liu, J. Surface properties of Mo-implanted PVD TiN coatings using MEVVA source. Appl. Surf. Sci. 2013, 280, 482-488. [CrossRef]

27. Woydt, M.; Skopp, A.; Witke, D.K. Wear engineering oxides/anti-wear oxides. Wear 1998, 218, 84-95. [CrossRef]

28. Terajima, T.; Takeuchi, F.; Nakata, K.; Adachi, S.; Nakashima, K.; Igarashi, T. Composite coating containing WC/12Co cermet and Fe-based metallic glass deposited by high-velocity oxygen fuel spraying. J. Alloy. Compd. 2010, 504, S288-S291. [CrossRef]

29. Bolelli, G.; Börner, T.; Bozza, F.; Cannillo, V.; Cirillo, G.; Lusvarghi, L. Cermet coatings with Fe-based matrix as alternative to WC-CoCr: Mechanical and tribological behaviours. Surf. Coat. Technol. 2012, 206, 4079-4094. [CrossRef] 
30. Bolelli, G.; Bursi, M.; Lusvarghi, L.; Manfredini, T.; Matikainen, V.; Rigon, R.; Sassatelli, P.; Vuoristo, P. Tribology of FeVCrC coatings deposited by HVOF and HVAF thermal spray processes. Wear 2018, 394-395, 113-133. [CrossRef]

31. Bolelli, G.; Colella, A.; Lusvarghi, L.; Puddu, P.; Rigon, R.; Sassatelli, P.; Testa, V. Properties of HVOF-sprayed TiC-FeCrAl coatings. Wear 2019, 418-419, 36-51. [CrossRef]

32. Federici, M.; Menapace, C.; Moscatelli, A.; Gialanella, S.; Straffelini, G. Pin-on-disc study of a friction material dry sliding against HVOF coated discs at room temperature and $300{ }^{\circ} \mathrm{C}$. Tribol. Int. 2017, 115, 89-99. [CrossRef]

33. Watremez, M.; Bricout, J.P.; Marguet, B.; Oudin, J. Friction, Temperature, and Wear Analysis for Ceramic Coated Brake Disks. J. Tribol. 1996, 118, 457. [CrossRef]

34. Öz, A.; Gürbüz, H.; Yakut, A.K.; Sağiroğlu, S. Braking performance and noise in excessive worn brake discs coated with HVOF thermal spray process. J. Mech. Sci. Technol. 2017, 31, 535-543. [CrossRef]

35. Wahlström, J.; Söderberg, A.; Olander, L.; Jansson, A.; Olofsson, U. A pin-on-disc simulation of airborne wear particles from disc brakes. Wear 2010, 268, 763-769. [CrossRef]

36. Federici, M.; Menapace, C.; Moscatelli, A.; Gialanella, S.; Straffelini, G. Effect of roughness on the wear behavior of HVOF coatings dry sliding against a friction material. Wear 2016, 368-369, 326-334. [CrossRef]

37. Federici, M.; Perricone, G.; Gialanella, S.; Straffelini, G. Sliding Behaviour of Friction Material Against Cermet Coatings: Pin-on-Disc Study of the Running-in Stage. Tribol. Lett. 2018, 66, 53. [CrossRef]

38. Wahlström, J.; Lyu, Y.; Matjeka, V.; Söderberg, A. A pin-on-disc tribometer study of disc brake contact pairs with respect to wear and airborne particle emissions. Wear 2017, 384-385, 124-130. [CrossRef]

39. Menapace, C.; Mancini, A.; Federici, M.; Straffelini, G.; Gialanella, S. Characterization of airborne wear debris produced by brake pads pressed against HVOF-coated discs. Friction 2019, 8, 421-432. [CrossRef]

40. ECHA. SVHC List. 2018. Available online: https://echa.europa.eu/it/candidate-list-table?p_p_id=disslists_ WAR_disslistsportlet\&p_p_lifecycle=1\&p_p_state=normal\&p_p_mode=view\&p_p_col_id=column1\&p_ p_col_pos=2\&p_p_col_count=3\&_disslists_WAR_disslistsportlet_javax.portlet.action=searchDissLists (accessed on 1 June 2020).

(C) 2020 by the authors. Licensee MDPI, Basel, Switzerland. This article is an open access article distributed under the terms and conditions of the Creative Commons Attribution (CC BY) license (http://creativecommons.org/licenses/by/4.0/). 